水文・水㾞源学会誌

J. Japan Soc. Hydrol. \& Water Resour.

Vol. 9. No. 4 (1996) $\quad$ pp. 358-366

\title{
Impact of Production Privatization on Onfarm Water Management in the Red River Delta, North Vietnam
}

\author{
私的生産制への移行が北ヴェトナム紅河デルタの戋場レベル水管理に与える影響
}

\section{DOAN Doan Tuan* \\ ドアン ドアン トゥアン \\ Masayoshi SATOH** 佐藤政良}

NGUYEN Thanh Nga***

グエン タン ンガ

\author{
Doctoral Program in Agricultural Sciences, University of Tsukuba
}

(筑波大学大学院農学研究科)

Institute of Agricultural and Forest Engineering, University of Tsukuba (筑波大学農林工学系)

Vietnam Institute for Water Resources Research

(ヴェトナム水資源研究所)

In the transition to a market economy, in the rural Vietnam areas, the right to conduct production subjectively has been returned from cooperatives to the farm households. This individualization motivates the farmers to carry out their farming practices effectively. However, onfarm water management, because of physical interdependency among the farmers, can hardly be effectively carried out without cooperation of all the interdependent farmers.

This paper, based on case studies of the main types of onfarm water management prevailing in the Red River Delta, analyses the changes in onfarm water management in the transition. It is found that, while the farmers carry out farming practices individually, the diminishing of the cooperative's role in onfarm water management is the main cause of the onfarm facilities' damages and unreliability of water supply to downstream area.

The downstream farmers, depending on the changes in the role of cooperative in water management, take different countermeasures. In the best cases where the cooperatives can mobilize resources for a supplemental water supply, the farmers have to spend much more money and labour than the upstream farmers. In the other cases, they could not do anything other than to suffer from water shortage and delay water fee payment.

The equity policy in water distribution and cost payment would enable the downstream farmers to invest in water recycling, thus increasing the system's efficiency.

The integration at the village level of hamlet traditional organizations would be an effective body for onfarm water management.

Key words: Red River Delta, North Vietnam, Production privatisation, Irrigation and drainage system, Onfarm water management

市場経珮への移行によって,ヴェトナムの農村地帯における農業生産の権利は, 合作社から農民に返還された.この個人経営制度 の導入によって, 農民の経営効率化への意欲が高まった. しかし, 固場レベルの灌敏はその共同的性格から, 一つの用水に関係する 農民の共同的活動なくしては奻果的な運用が出来ない. 本論文は, 紅河デル夕における形態の異なる水管理地区の調査に基づき,こ の経済の移行が, 固場レベル水管理にいかなる変化をもたらしているかを分析した，その結果, 農家による個別経営运入の一方で,

\footnotetext{
*筑波大学大学院農学研究科 $\mathbf{T} 305$ 茨城県つくば市天王台 $1-1-1$

Doctoral Program in Agricultural Sciences, University of Tsukuba, Tenno-dai 1-1-1, Tsukuba-shi, Ibaraki, 305 Japan

**筑波大学農林工学系 $=305$ 茨城県つくば市天王台 1-1-1

Institute of Agricultural and Forest Engineering, University of Tsukuba, Tenno-dai 1-1-1, Tsukuba-shi, Ibaraki, 305 Japan

***ヴェトナム水資源研究所

Vietnam Institute for Water Resources Research, Tay Son Street, Dong Da, Hanoi, Vietnam
} 
水管理における合作社の役割が消失してしまったことが紅河流域における灌溉排水施設の被害や灌溉用水の下流部受益地に対する 用水配分の減少, 不安定化を生じさせていることを明らかにする。このような状況に対して, 下流部受益地農民は, 地域による合作 社の機能変化の䢖いによって, 様々な対応をみせる. 幸いにも合作社の機能が比較的強く牫っている地域では, 補助水源の開発を行 うことができるが，その受益農民は，上流部の農民に比べてはるかに多額の水管理費と労働を支出せざるを得ない。他のケースて は, 水不足に対してなんら実質的な対策をとることが出来ず, 水不足の被害を受けても，せいぜい水利公社に対する水利費の支払を 延ばしてもらう程度である，用水配分および費用負担の公平を政策的に打ち出すことによって，下流地域農民の用水反復利用への投 資が実現し，水利システム全体としての灌溉効率を上昇させることが出来るであろう。また, 現在ても残っている伝統的集落組織を 村レベルで組織化することが，水管理組織として有効なものになるであろう.

キーワード：紅河デルタ, 北ヴェトナム, 生産の個人化, 灌溉排水システム, 直場レベル水管理

\section{I . INTRODUCTION}

The Red River Delta, in North Vietnam, covering an area of around 1.5 million ha(Fig. 1), is one of the main rice production areas in Vietnam. A cultivation year is devided into three seasons, summer rice (June to October), winter subsidiary crop or fallow (October to January), and spring rice (February to June). The remarkable seasonal change of rainfall from $1400 \mathrm{~mm}$ in summer season to $300 \mathrm{~mm}$ in winter-spring season causes severe flood and drought damages to the production in the Delta. To ensure the development in the Delta people have continuously improved the dyke systems and canal networks (Yasuyuki Kono et al. 1995).

During the process of agriculture cooperativization 1959-1980, the irrigation and drainage was highly promoted. This created the prerequisite condition for the cropping system evolution and

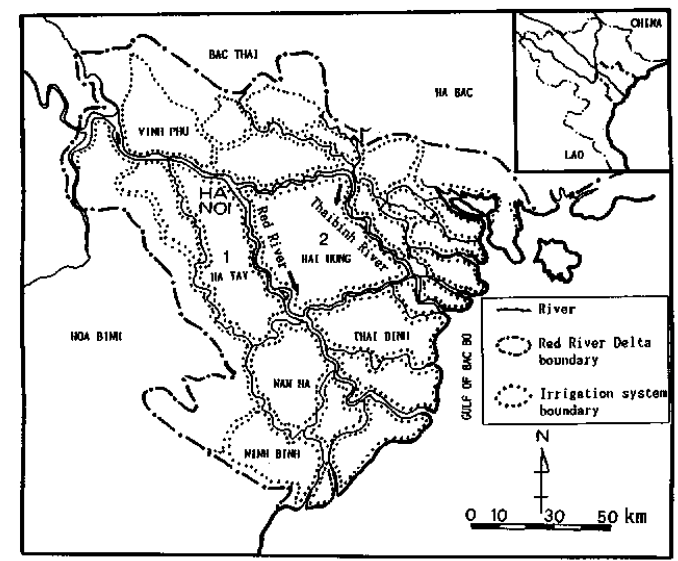

Fig. 1 Red River Delta and irrigation and drainage systems the introduction of the high yielding rice varieties in the last few decades (Tran Viet Chi et al. 1993). However, the agricultural productivity showed little improvement (Vietnam Foreign Languages Publishing House, 1990).

As a measure to deal with the slow production increase, the renovation of economic policy in agriculture has recently been carried out. The farmers, with motivation from the new policy, have eagerly invested in the production. As a result, rice production has increased dramatically. However, unlike other farming practices, irrigation and drainage, with its interdependent characteristics, cannot easily find a successful direction, especially in onfarm water management. This may threaten the sustainable agricultural production in the Delta.

This paper presents the analysis of the progress that farmers have gained and the changes that are going on in the field of irrigation and drainage management after production privatization in the delta.

\section{IRRIGATION AND DRAINAGE DEVELOPMENT IN THE RED RIVER DELTA}

1. Traditional land ownership, village collective works, and onfarm water control

A village is a cell in Vietnam rural areas. In the Red River Delta, it is composed of a residential area surrounded by ponds, waste lands, and 350-450ha of farmland. Before the seventeenth century, in a village the farm land was registered as commune land and redistributed to villagers once every several years. Since the seventeenth 
century, with the institutionalization of private land, the land lord class appeared (Phan Huy Le et al. 1993).

In the rural Red River Delta, because of small farm size and subjection to frequent flood and drought, the co-relationship among village's farmers was formed and strengthened by the necessity of the building of dykes to protect the common living area and cultivated areas from floods; and by the necessity of the creation of an irrigation and drainage system for common cultivated land. The irrigation system was based on the terrain and so there was only common network for an entire village until the beginning of the nineteenth century.

In terms of settlement, a village is further divided into hamlets with 50-70ha of farmland where mutual aid usually took place among the farm households for daily life and production activities. The hamlet was also the territorial unit for a village's collective security. The hamlet's patrol was placed under the control of the village administration. All the men aged 18 or older fulfilled duty by preventing theft and banditry, and by conducting water control works such as consolidating the dykes and maintaining the canals. Through the course of water control, the village formed a basic rural unit, upon which a water management body was founded with a hamlet as it's sub unit, where daily life activities, including water management were performed.

2. Land reform, cooperative movement, and formation of onfarm water management organization

In 1953-1956, land reform was carried out in Vietnamese villages. The land in the hands of the landlords and the rich was confiscated and redistributed to the peasants. In 1959 , and subsequently in 1965 the government launched the movement for building hamlet scale agricultural cooperatives, with the collectivization of all means of production and the distribution of products done according to one's contribution in the form of labour. As "Irrigation is a measure of prime importance" (Resolution of the Central Committee' s, 5th conference on agricultural development, 1961) for production, irrigation was promoted and fields were reconstructed. Since 1970 , to fit irrigation and field reconstruction with micro topography and basic rural unit, the cooperative being hamlet scale, had been grouped into a village scale cooperative with specialized production teams such as seed, land preparation, and water management teams.

To carry out the irrigation networks, the teams specialized in hydraulics construction were formed. The hydraulic construction works were carried out in such a way as to make full use of the old canals and streams, transforming and joining small old streams into a main, and digging new canals joining the irrigation and drainage project conducted by the government. The small irrigation works, with drains and ditches, were constructed for each area 3-8 ha in size. Inside each area, there was a system of levees dividing the area into a small block $1250-2500 \mathrm{~m}^{2}$.

For water management and maintenance of a village's irrigation network, a team specialized in irrigation and drainage was formed. As the cooperative's production was centralized and strongly controlled by the government, the cooperative delivered water following its interest. Depending on the field and canal layout, the water delivery was done to each block separately (Fig. 2) or from block to block. The farmers did not have much incentive in productivity's increase in the

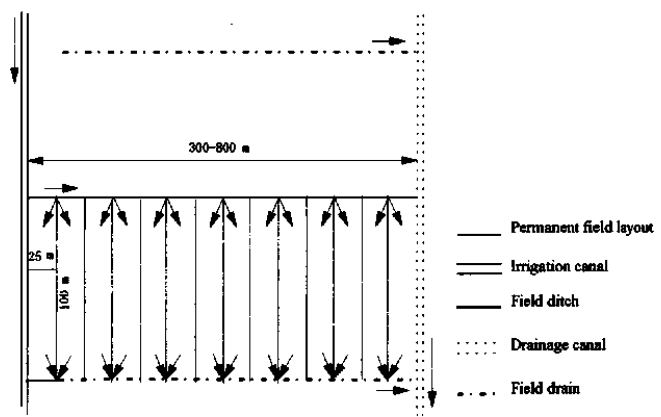

Fig. 2 Field layout and water management during cooperative movement 
fields where they worked. Therefore there was no background to cause water conflict between upstream and downstream farmers. With the aim of maximisation of the total production in the village, even water distribution was a target, and was smoothly carried out.

\section{Irrigation and Drainage Systems Develop- ment in the Red River Delta}

The present irrigation and drainage systems were constructed from the beginning of the nineteenth century to 1972 and have been subsequently improved since 1973 . Thirty principle irrigation and drainage systems with command areas ranging from 5000 to 120000 ha have been developed inside the dyke enclosures making use of the existing natural water way for both irrigation and drainage (Fig. 1). Water is brought into the systems via gated intakes, supplemented by medium scale pumping stations. Such pumping stations commanded different parts of a big system and form sub systems inside one principle system. Nowadays, in the Red River Delta, there are 59 Irrigation and Drainage Management Companies (IDMC) established according to provincial or district boundaries. These IDMC are operating and maintaining the main facilities of the irrigation systems.

It is institutionalized that the structures and canals serving an area bigger than 250ha are implemented by the government. The ditches serving an area less than 250ha are dug by the farmers. In addition, the farmers have to pay the water fee for system operation and maintenance. The water fee charged to farmers are $3-8 \%$ of the rice yield for full irrigation and drainage; and $70 \%$ of that level as basic water fee for partial irrigation and drainage. Full irrigation and drainage area is defined as the area where the farmers get an drain water without their additional effort for lifting works; the remaining part of the IDMC command area is regarded as partial irrigation and drainage area.

During the centralized economy, the mobilization and involvement of farmers in irrigation and drainage construction and onfarm water management by cooperatives in the Red River Delta was successfully carried out. It is estimated that the investment in the irrigation and drainage made by the farmers occupies more than $30 \%$ of the total investment invested in irrigation and drainage works in the delta (Ministry of Science, Technology and Environment, 1993). Through the effort of both the government and farmers, the major irrigation and drainage achievements were gained between 1960 and 1980 . Compared to the irrigated land in 1945 , the land that was brought into irrigation during this time increased by $200 \%$ (Fig. 3) .

\section{ONFARM WATER MANAGEMENT CHANGES INDUCED BY PRODUC- TION PRIVATIZATION}

\section{Renovation of economic policy in agricul- ture}

Though the cooperative movement from 1959 to 1980 had formed a main material base for large scale production, this could not give rise to high productivity. To deal with the decline in the production, in 1981 the government issued Directive No. 100 on the implementation, in favour of peasant households, of the regime of contract on products, and finally in 1988, the resolution No. 10 on the contract of final products to every household or group of households was carried out. It ensures the farmers the right to use the

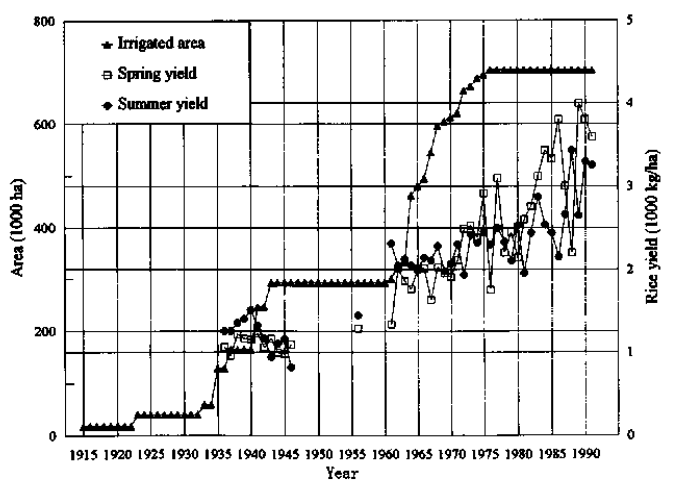

Fig. 3 Irrigated land and rice yield in the Red River Delte 
land for production for a period of 15 years with stabilized clauses of contracts for a period of 5 years. The role of the basic economic unit has been returned from the cooperatives back to the farm households. The farmers' only obligation is to pay the agricultural tax. The farmers, motivated by the new policy, have eagerly invest. ed in the production, and as a result rice production has increased dramatically (Fig. 3).

\section{Changes in onfarm Water Management}

In production privatization the role and tasks of cooperative in production management have decreased, and the cooperative has gradually become a service organization, while the role and tasks of individual farmers have risen, and households have become economic subjects in rural areas. However, unlike other farming practices that are effectively carried by individual farmers, irrigation and drainage practices, due to physical interdependency among farmers cannot easily find a successful direction, especially in onfarm water management.

After directive No. 100 was issued in 1981 on the implementation of the regime of contract on products, the cooperative still managed most production activities. However the onfarm water management was divided and managed by two bodies. The cooperative plays the role of the water manager from the turnout of secondary canals into tertiary canals to the last permanent canals and negotiator with other cooperatives during the time of water shortage or heavy inundation; and hamlets who are in charge of water distribution among hamlet's farmers.

After the resolution No. 10, issued in 1988, the cooperative no longer had the role of production manager. It stopped acting as production unit and water management unit and eventually becomes a service organization.

Figure 4 illustrates the changes in onfarm water management in the Red River Delta during the cooperative movement and after renovation in agriculture. Before production privatization in agriculture, water management was performed

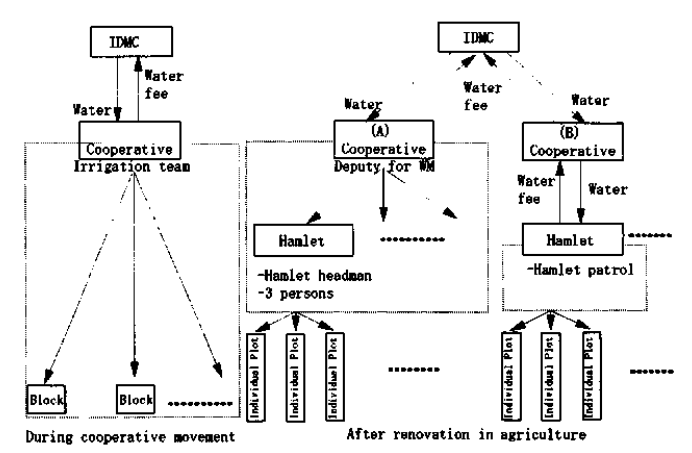

Fig. 4 Change in onfarm water management

by the cooperative, who distributed water to all its field block of $1250-2500 \mathrm{~m}^{2}$ in size. After the introduction of private production, field blocks were divided into plots of $300-400 \mathrm{~m}^{2}$ in size and distributed to farmers for long use. To match the changes in production practices, onfarm water management has also changed. At the present, there exist two main types.

\section{1) Cooperative as water manager, a case of Phulam village}

Phulam village belongs to Lakhe district, $\mathrm{Ha}$ -Tay Province, located in south western Hanoi. The village consists of three hamlets. It has a natural area of 207ha, whose agricultural land is $150 \mathrm{ha}$ and cultivated land is $144 \mathrm{ha}$. There are 877 agricultural households. Phulam village gets its water supply from Lakhe irrigation and drainage sub-company, taking water from Nhue irrigation and drainage system (No. 1 in Fig. 1). The Phulam cooperative consists of three production teams established for each hamlet. The hamlet head man is also the head of the production team.

The water management is taken by the water service team, which is consisted of the deputy head of the cooperative, the hamlet head man and three other persons from each hamlet (see (A) cooperative in Fig. 4).

The water management members "think and discuss which part of the canal is to be broken and which part must be filled in order for the farmers to have water". During land preparation and rice transplanting the water is delivered simultaneously, and the fields' levee is broken by members of 


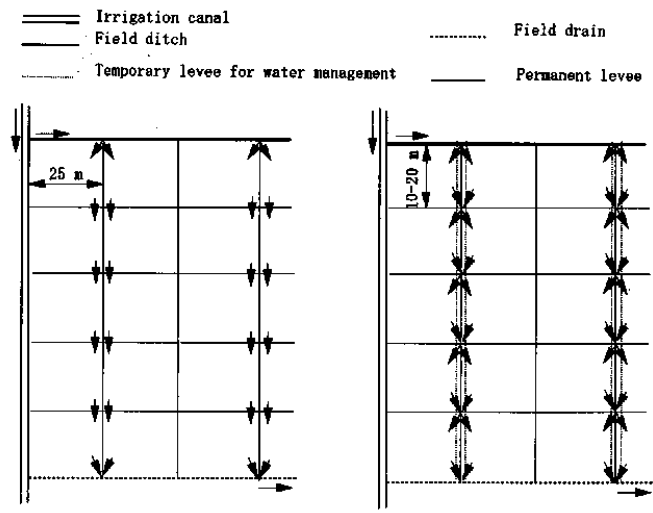

(a) During land preparation and transplanting

(b) After transplanting

Fig. 5 Field layout and water management after production privatization

the water service team for the water to flow from plot to plot (Fig. 5(a)). After the transplanting, the broken levee is rebuilt and the farmers, temporally build additional levees to convey water from last permanent canals into their individual fields. Though this method makes the farm's plot smaller, it gives them independence in water management and allows farmers to get water without disturbing his neighbours' crop care activities such as fertilizer application. (Fig. $\mathbf{5}(\mathbf{b}))$.

For the irrigation water, the farmers pay 300 $\mathrm{kg} / \mathrm{ha}$ of rice for spring rice season and $250 \mathrm{~kg} / \mathrm{ha}$ for summer rice season to the irrigation and drainage management company. In addition, they pay $90 \mathrm{~kg} / \mathrm{ha}$ of rice for spring season and 70 $\mathrm{kg} / \mathrm{ha}$ for summer season to the cooperative for onfarm water management. This payment is then given to the water service team of which $30 \%$ is given to the team members as the allowance, the other $70 \%$ being the expenditure for the repair of the ditches and canals.

Water management of type one exists in the villages where, perhaps thanks to the existence of strong cooperative leaders, the cooperative remains influential. Though it has become a service organization it still manages some interdependent activities that could not be carried out successfully without collective action. The role of water manager is still taken by the cooperative in the form of water service team.

2) Hamlet's farmers as water manager, the case of Phuluong village

Phuluong village is Phulam neighbour. It gets water from and drains water into the same irrigation and drainage canals as Phulam. However, the village is at a disadvantage because it is located at the end of a secondary canal conveying water to both villages.

Phuluong has 472ha of rice land, and it consists of 8 hamlets that are the production teams. Among them, only 2 hamlets can get water sufficiently. The rest depend on the return flow in the drainage canals. The deputy head of Phuluong cooperative is responsible for making an irrigation and drainage contract with Lakhe company, and inform hamlets each time when the water is delivered. The water fee depends on how available the water is to hamlets ranging from $280 \mathrm{~kg} /$ ha to $530 \mathrm{~kg} / \mathrm{ha}$ per season, and this differs from hamlet to hamlet. The high water fee in some hamlets is caused by the expenditure on operation and maintenance of pumps. The actual fee collection is reported to be $70 \%$ of what was set. In addition to the payment to the cooperative, the hamlet's farmers also either have to pay for water management within their cultivated areas or provide for it with their labour. The hamlet water management (among other duties) is taken by the hamlet patrol (see (B) cooperative in Fig. 4) consisting of 10 young men motivated by the old people in the hamlet. This patrol is changed once a year according to the hamlet's unwritten rules. The irrigation works lose the collective characteristic at the village scale. There seems to be no ownership of the facilities from the turn out of secondary canals to the last permanent canals serving several hamlets. The maintenance of the facilities in this area is weakened and the farmers break the canals to get the water each time they need it. Onfarm irrigation and drainage facilities are being damaged. Unorganized water use is wasting water and causing the water dispute to 
arise.

Water management of type two exits in most of the villages, where the cooperative completely becomes a service organization, and the irrigation team is weakened or actually disappears.

The case of Phuluong village shows that in the case of a scarce water supply, and where the water condition varies substantially from hamlet to hamlet, it is difficult to maintain the role of the cooperative as a water manager. At present, the cooperative has no background or ability to settle water conflict among hamlets.

\section{Uneven Water Distribution}

As the cooperative gradually stops functioning as a water management unit, and while another strong integrated water management body has not yet been formed, farm households have to undergo the task by themselves and obtain water individually. It is natural that uneven water distribution arises and water is wasted. The tail end of the canals' areas of the end level of irrigation network suffer water shortages.

The negative effect of independent water intake by many farmers within a village is further increased as a result of independent water intake by many villages within a system. This leads to unreliable water supplies and decreases in the irrigated area formerly commanded by IDMC downstream.

Figure 6 presents the changes in the irrigation area in Phuluong village since 1985 . The formerly full irrigation area of 350 ha by Lakhe sub-company was quickly reduced by $60 \%$ and became 150 ha just after the introduction of production privatization.

Figure 7 shows the decrease in area irrigated by Caughe pumping station, Cambinh district, Hai-Hung province, located in the East of Hanoi. Caughe pumping station is operated by Cambinh irrigation and drainage sub-company, and takes water from Bac-Hung-Hai irrigation and drainage system (No. 2 in Fig. 1). In 1985 this pumping station irrigated 1000 ha of paddy rice. Since 1989 , the irrigated area rapidly decreased and became 650ha in 1995 .

To deal with the water shortage as the result of uneven water distribution, the downstream farmers who live where the cooperative can mobilize resource to construct small pumping stations can get water from the drainage canal to irrigate their rice fields.

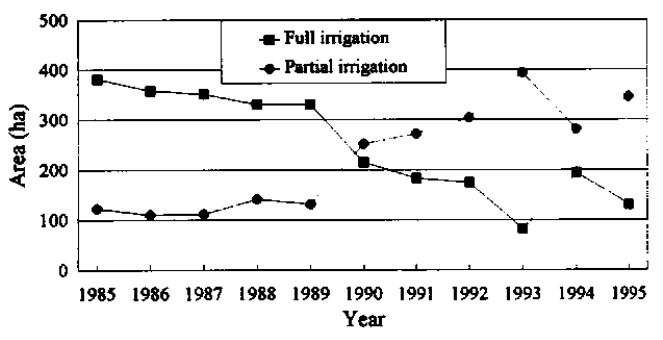

Fig. 6 Change in irrigated area in Phuluong Village

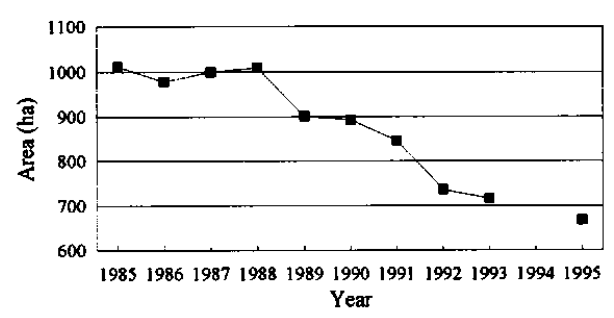

Fig. 7 Change in area irrigated by Caughe pumping station

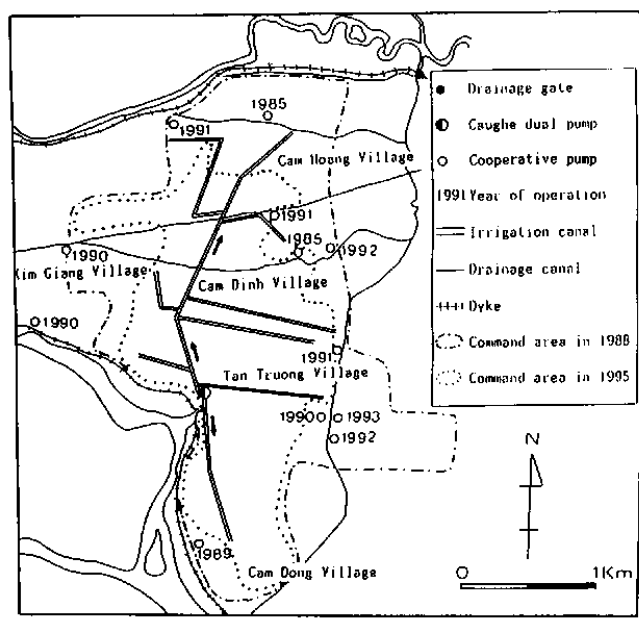

Fig. 8 Cooperative-managed pump development and changes in Caughe pumping station's command area 
Figure 8 illustrates the process of the development of small pumps and differences in areas commanded by Caughe pumping station between 1988 and 1995. It shows that most of the pumps were constructed after the introduction of production privatization in 1988. All the pumps were constructed in the downstream areas and get water from drainage canals. Farmers in these areas chose not to remain under the control of the Cambinh sub-company by changing their land to partial irrigation areas. In addition to payment to Cambinh sub-company for partial irrigation, the farmers pay fees toward the cooperative for onfarm water management. By using their own pumps, the water delivery is stable, though the farmers have to pay more than for the full irrigation provided by the irrigation company. There are many villages where the farmers pay $60 \%$ higher than the other area receiving full irrigation directly from the irrigation company. The water fee is set by the farmers' agreement in the cooperative meeting.

The farmers in villages where the cooperatives could not mobilize resorces for a new source of water supply suffer from severe water shortage during a drought. They cannot do anything other than to refuse to accept all the area as full irrigation and delay water fee payment, as in the case of Phuluong village and many others in the delta.

\section{Treatment of inequity}

In the Red River Delta, the lack of co-ordination in water management at the system level due to the independent operation of irrigation and drainage companies are well recognized, and measures are being made to encourage the water management according to the system boundary (Ministry of Science, Technology and Environment, 1993). However, the benefits of equity in terms of water supply and cost payment are not well known and then there has not been any measure to overcome the inequity between upstream users and downstream users, between advantageous and disadvantageous areas.

The ceiling for the water fee toward IDMC is set up by the government, and the actual norm is then decided by each provincial authority. However, the farmers' payment for the onfarm water management is decided by the water user groups independently, depending on the expenditures. Thus the farmers upstream enjoy much for the upstream advantages, while the downstream farmers suffer from water shortages, especially during severe droughts. The cost payment for water recycling that increases system water use efficiencies is shouldered by too small a number of farmers of limited downstream areas, thus it is difficult to be realised. This puts limitations on full exploitation of the given water resource.

One of the different ways to deal with this problem has been performed in Japan by the Land Improvement District, which is a private association of farmers. The farmers normally pay the same water fee or membership fee, part of which is used for water recycling in downstream areas. This means that the farmers upstream are compensating for the downstream farmers for the disadvantage in water use. Moreover, the rotational water delivery system is performed in case of a severe water shortage (Satoh, M. et al . 1990).

The equity policy in water delivery and cost payment motivates the farmers in disadvantaged areas participate in the project thus increasing water use through water recycling thus the total production increases as the water supply becomes stable and the irrigated area is increased.

\section{IV . CONCLUSION, RECOMMENDATION}

During the centralized economy, the cooperative, formed on the village base, was an effective body for mobilization and involvement of farmers in irrigation and drainage construction and onfar$\mathrm{m}$ water management. Thanks to this, major achievements in irrigation and drainage have been gained at both the system level and farm level.

In the transition of the economy to more market orientation, along with the gradual change of 
the role of the cooperative as a production management body to a service body the integrated body for onfarm water management is gradually weakening. As a result uneven water distribution is arising, onfarm facilities are being damaged. The areas irrigated by the state irrigation and drainage companies are decreased due to unstable and unreliable water supplies in the downstream areas. The farmers who live where the cooperative can mobilize resources for small pumping stations can get return water flow for irrigation with high expenditures. In other cases, the farmers suffer from severe water shortage and delay water fee payment. Ways should be sought to ensure that the constructed facilities are not damaged and the ability to undertake the collective action for successful irrigation is not lost. The equity policy in water distribution and cost payment should not be neglected as it reduces the burden that is shouldered by small downstream area farmers and motivates them to participate in projects and increase irrigation and drainage efficiencies.

The cooperative, once becomes a service body, may not have the background to deal with water management effectively, especially during severe drought and flood. Thus, the farmers should be encouraged to take the task themselves through the integration of water management organizations at the hamlet level, into a water management body which different from a service organization at the village level

\section{REFERENCES}

1) Foreign Languages Publishing House (1990) : The renovation of agricultural economic management, p. 7, Hanoi, Vietnam

2) KONO, Y. and DOAN, D.T. (1995) : Effect of water control on rice cultivation in the Red River Delta, Vietnam: A case study in the Nhue River irrigation system, Journal of Southeast Asian Studies, 32, (4), pp. 425-445 (1995)

3 ) Ministry of Science, Technology and Environment (1993) : Report on irrigation and drainage in the Red River Delta, pp. 11-12, 51-52, Hanoi, Vietnam (in Vietnamese)

4) PHAN, H.L. et al . (1993): The traditional village in Vietnam, 458 pp., The Gioi Publishers, Hanoi, Vietnam

5) SATOH, M. et al. (1990) : How to settle water users' conflicts during droughts in Japan, Trans. of 14th Congress on Irrigation and Drainage, I-C, pp. 141-150

6) Statistical Publishing House (1991): Thirty five year agricultural statistical data, 602 pp., Hanoi , Vietnam (in Vietnamese)

7) The Government of Vietnam (1961) : Resolution of the Vietnamese Central Committee's 5 th conference, Hanoi, Vietnam (in Vietnamese)

8) TRAN, V.C. et al. (1994) : Red River Delta master plan, Agricultural sector working paper (Draft), 58 pp., Hanoi, Vietnam （1996年 2 月 6 日受付，1996年 5 月10日受理） 